\title{
The Effectiveness of Neuro Muscular Electrical Stimulation on Hand Function in Sub Acute Stroke Survivors: A Systematic Review of Randomized Controlled Trials
}

\author{
Nainky Bhalla, Navkaran Shergill and Simranjeet Kaur
}

\begin{abstract}
Background: Role of Neuro Muscular Electrical Stimulation on hand function in patients with stroke has not being well established. Objective: To estimate the effectiveness of Neuromuscular Electrical Stimulation in improving hand function of patients with sub acute stroke. Data Source: Systemic search was carried out in Medline, Cochrane and Pubmed Databases from August 2018 to June 2019. Study Selection: Randomized controlled trials. Eligibility criteria: subjects $>18$ yrs suffering from haemorrhagic /ischaemic stroke within 6 months, NMES as intervention applied on affected hand using surface electrodes, outcome measures related to skeletal, muscular and functional characteristics of arm and statistical analysis of results. Data Extraction: Participant's characteristics, NMES parameters, and other relevant data was extracted from the articles and then tabulated. Cochrane collaboration's tool for assessing risk of bias was applied to all articles and methodological quality was assessed by PEDro scale. Data Synthesis: Eighty-one articles were selected through database and citation by title content, 48 articles were screened after reading the abstract. 31 full text articles were found and 15 comply with inclusion criteria. The methodological quality of the articles was assessed through PEDro scale which was between 5/10 and 8/10. Beneficial impact of NMES on muscle tone, motor function, manual dexterity and upper limb

ADL's was established in level of evidence synthesis. Limitation: It was difficult to group studies and quantitatively evaluate outcomes due to the variance in protocol s, participant features, outcome measures and NMES parameters. Conclusion:Randomized trials ha ve shown beneficial impacts of electrical stimulation on the wrist and hand despite methodological constraints, implying that NMES is efficient in encouraging the impacted hand in stroke.
\end{abstract}

Nainky Bhalla

RIMT University

Mandi Gobindgarh ( Punjab),India

Email: nainky@gmail.com

Navkaran Shergill

RIMT University

Mandi Gobindgarh ( Punjab),India

Email: navkaran9999@gmail.com

Simranjeet Kaur

Punjabi University Patiala (Punjab) India

simraniar363@gmail.com

\author{
Keywords: Hemiplegia, Stroke, Electrical \\ stimulation, Hand \\ DOI: 10.18376/jesp/2019/v15/ i2/153525
}

\section{Introduction}

Stroke is a major health care problem and an important cause of morbidity and mortality (Gourie 2008). Among neurological disorders in adults, it is a major cause of disability which can result in highly complex clinical conditions (Wilson et al., 2016 ). It is third major cause of death worldwide and nine out of ten strokes occur in people over the age of 55. In India, the prevalence of stroke is 


\section{Journal of Exercise Science \& Physiotherapy Vol. 15 No. 2 (July to December) 2019 ISSN: 0973-2020 (Print) I I OR Impact Factor =6.502 ISSN: 2454-6089 (Online)}

44-843/100,000, and according to the Indian Council of Medical Research 2015 India reports 1.6 million cases of stroke per year. In India stroke population is relatively young (Indian population $>=60 \mathrm{yr}: 7.5 \%$ ) as compared to the western countries (British population $>=65 \mathrm{yr}$ ) (Mishra and Khadilkar 2010).Hand dysfunction such as difficulties in grasping, reaching, manipulating objects is most common consequences of stroke (Lai et al., 2002). These chronic problems lead to difficulty in performing functional movement such as picking up a glass, buttoning a shirt in post stroke patient and leads to difficulty in performing tasks of daily living and limit their community participation (Gowland et al., 1992). Even in stroke survivors, whose neurocognitive function are upgraded, 55-85\% of the sufferers continue with upper limb dysfunction (Nakayama et al., 1994). In upper limb recovery, the regaining wrist and fingers control is challenging and the impaired hand function is one of the remaining consequences of stroke (Lee et al., 2012). As per the literature, it is assumed that only 5 to $20 \%$ of the stroke sufferers gain complete functional recovery of their affected upper limb and remaining 70-80\% continue with upper limb impairment and do not regain functional use of paretic upper extremity (Kwakkel et al., 2003). Thus the post stroke rehabilitation techniques are growing interest in neurophysiological therapy, since it can improve the functional outcome and quality of life to many stroke survivors. Neuro muscular electrical stimulation (NMES) is a neuroprosthetic technique which applies programmed short electrical pulses to the muscles affected by stroke for restoring lost motor function. It can be either applied to the hemi paretic muscles or to the peripheral nerve system associated to the hemiplegia. Neuro muscular electrical stimulation is used for correction of contractures, muscle strengthening, and facilitation of voluntary motor control and increased passive range of motion. The NMES is also used for improvement muscle spindle reflex activity (Glanz et al., 1996).Recent clinical studies promote the use of NMES for the recovery of muscle strength after stroke. NMES specific for the upper limb rehabilitation is receiving increasing attention as a therapeutic modality due to clinically significant results (Weingarden et al., 1998).

Nowadays NMES is used to improve gait and upper limb function in patients suffering from stroke. Its use in regaining wrist and finger control is yet to be established. Hand is driving force for upper limb recovery after stroke. Recovery of hand function spans from regaining power grip to single digit individuation. Despite the promising advantages of NMES in stroke, there is lack of understanding of the appropriate stimulation parameters for NMES for wrist extensors (Warlow et al., 2008). Many clinical trials had shown the impact of NMES on the wrist and fingers of hemiparetic patients (Gondkar et al., 2019; Jonsdottir, et al., 2017; Etoh, et al., 2015 ; Francisco et al., 1998). Therefore, a systematic literature review would assist in the planning of intervention by providing a synthesis of the evidence on the impacts of this useful resource. The study aims to perform a systematic literature review using sound selection and analysis of scientific papers that investigate the impact of this stimulation.

\section{Materials and Method}

\section{Data source and search:}

A systemic search for randomized control trials in the digital databases Medline, Cochrane and Pub med was conducted between August 2018 and June 2019.The keywords used were: "electrical stimulation" or "neuromuscular electricalstimulation" and "wrist" or "hand" or "paresis with "stroke", "hemiplegia", "dexterity" and "CVA".

Study Selection: The studies which fulfilled the following inclusion criteria: subjects $>18$ yrs suffering from haemorrhagic /ischaemic stroke within 0-6 months, NMES as intervention applied on affected hand using surface electrodes, presence of control group with randomization, outcome measures related to skeletal, muscular and functional characteristics of arm and statistical analysis of results was selected. 


\section{Journal of Exercise Science \& Physiotherapy Vol. 15 No. 2 (July to December) 2019 ISSN: 0973-2020 (Print) $\quad \mathrm{I}_{2} \mathrm{OR}$ Impact Factor $=6.502 \quad$ ISSN: 2454-6089 (Online)}

Data Extraction, Risk of Bias and Quality Assessment: Full text of selected article was recovered and assessed according to the selection criteria. The information in the studies was condensed in a tabular manner according to: author(s) name, characteristics of the participants, methodological design, characteristics of intervention (session frequency and duration, total treatment time and stimulation characteristics), outcome measured, statistical analysis used and results. Cochrane collaboration's tool for assessing risk of bias was applied to all articles. The studies were also evaluated using the PEDro scale for their methodological quality (PEDro). This scale is made up of 11 items, each item adding 1 point (except for item 1). The total score varies from 0 to 10 . Risk of bias and quality assessment information was considered in interpretation of finding.

Data Synthesis and Analysis: Eighty-one articles were selected through database and citation by title content. Sixty nine studies were left after duplicates were removed .Twenty one records were excluded of non RCT, old records (before 2015), non stroke records. Thereafter 48 articles were screened for abstract out of which only thirty one full text articles were found and just 15 articles complied with the inclusion criteria. The methodological quality of the articles was assessed through PEDro scale which was between 5/10 and 8/10. Table 1 shows the summarized data extracted from each article. Article scores in each item of the PEDro scale is shown in Table 2.

Two writers separately evaluated each article in relation to the existence or lack of indexes of the quality scale. The PEDro scale showed moderate rates of reliability among assessors (ICC $=0.68$; IC 95 percent $=0.57-0.76$ ). Differences of view were discussed for the final classification of the article until a consensus was reached between writers. It was not possible to carry out a meta-analysis because there was differences in characteristics of patients, intervention protocols and measured outcomes or insufficient quantitative data (standard deviation means) in the examined studies, therefore a result summary was used by means of an evidence level classification system shown in Table 3. The classification, included five scientific evidence categories according to the PEDro score and the results are available in the studies (Van et al., 2004).

\section{Results}

Eighty one studies were pre-selected by title content. After the abstracts were read, 48 articles were selected, of which 32 were excluded for failing to comply with the inclusion criteria. Therefore, 15 studies, all of them controlled and randomized, were included in the critical evaluation phase.

The information in the studies was condensed in a tabular manner, according to: author(s) name, characteristics of participants, evaluated results, methodological design, characteristics of intervention (session frequency and duration, total treatment time and stimulation characteristics), used statistical analysis and effects of outcome. The included studies contained total of 811 participants out if which 467 participated in intervention group and 344 in control group. The mean age of participant was 57.32 yrs and mean duration of stroke was 4.46 months.

\section{Participants' characteristics}

Five of the assessed studies included subjects diagnosed with acute stroke, with duration period of one to 2 month (Qian, et al., 2018 ; Marquez et al., 2017 ; Park et al., 2017 ; Schick et al., 2017; Kwakkel et al., 2016). Rest all assessed studies had a sample with sub acute stroke diagnosis, with duration periods varying from 3 month to 8 months. The sample size ranged from 17 to 159 subjects which were divided into treatment and control group. The participant's average age was between 40 to $75 \mathrm{yr}$. Both right and left hemiparesis subjects were included in the study. The severity of the damage was defined in various ways. Participants, however, had to show at least $10^{\circ}$ to $20^{\circ}$ of active wrist and fingers extension in all research. 


\section{Journal of Exercise Science \& Physiotherapy Vol. 15 No. 2 (July to December) 2019 \\ ISSN: 0973-2020 (Print) $\quad \mathrm{I}_{2}$ OR Impact Factor $=6.502 \quad$ ISSN: 2454-6089 (Online)}

\section{Risk of Bias and Quality Assessment}

Table 4 details the full critical appraisal information of all articles. Included studies span a arrange of methodological quality, eight studies had low risk of bias (Carrico et al., 2018 ; Schick et al., 2017; Marquez et al., 2017; Al Dajah \& Salameh. 2016; Kwakkel et al., 2016; Wilson et al., 2016; Kim et al., 2015; Kim et al., 2014), four studies had unclear risk of bias (Demir et al., 2018 ; Guo et al., 2018 ; Qian et al., 2018 ; Cui et al., 2015) and three studies had high risk of bias (Nakipoğlu et al., 2017 ; Park et al., 2017; Nagapattinam et al., 2015).

Quality assessment using PEDro criteria found medium quality evidence in all analysis performed as a result of the heterogeneity and lack of blinding in most of the studies.

\section{Intervention program characteristics}

Intervention duration varied from 12 (Guo et al., 2018 ; Nagapattinam et al., 2015) to 80 sessions (Demir et al., 2018 ; Marquez et al., 2017 ; Wilson et al., 2016 ) with seven of the articles having an intervention period of 20 (Kwakkel et al., 2016) to 30 sessions (Qian et al., 2018 ; Nakipoğlu et al.,2017 ; Park, et al., 2017 ; Cui et al., 2015 ; Kim et al., 2015 ; Kim et al., 2014). Application of NMES varied from 1 to 2 (Qian et al., 2018 ; Kwakkel et al., 2016; Wilson et al., 2016) times a day, from 3 (Guo et al., 2018) to 6 (Carrico et al., 2018 ; Qian et al., 2018 ; Al Dajah et al., 2016 ; Nagapattinam et al., 2015) times a week. Session duration varied from 20 minutes (Al Dajah et al., 2016) to 120 minutes (Carrico et al., 2018). Current parameters varied, with frequency ranging from $20 \mathrm{~Hz}$ (Wilson et al., 2016) to $60 \mathrm{~Hz}$ (Kim et al., 2015), amplitude from $20 \mathrm{~mA}$ (Kim et al.,

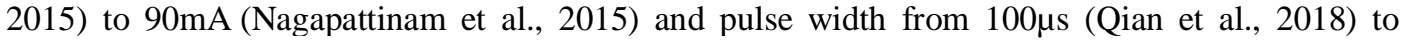

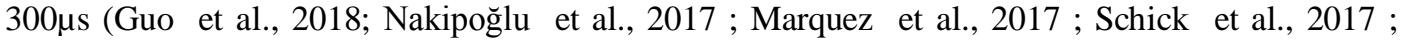
Wilson et al., 2016; Cui et al., 2015). In all studies, NMES was applied to extensor muscles of wrist and finger.

\section{Effects of FES on neuromuscular and musculoskeletal characteristics}

Hand strength

With the help of the hand grip dynamometer, two randomized controlled trials (RCTs) (Demir et al., 2018 ; Kim et al., 2014) measured the hand grip isometric force and found significant gains in the NMES treated group. Though these gains were higher than the control group in both studies but there is low evidence of the increase in isometric strength after NMES for power grip.

Wrist tonus

Tonus was evaluated using Modified Ashworth scale and Brunnstorm hand grading in four RCTs (Demir et al., 2018; Nakipoğlu et al., 2017; Cui et al., 2015 ; Kim et al., 2014). All the four trials showed a substantial decrease in tone compared to the control group only in the high-functioning group (at least $20^{\circ}$ of active wrist extension). and no important decrease was observed in the lowfunctioning group (active extension between $10^{\circ}$ and $20^{\circ}$ ) (Nakipoğlu et al., 2017). Qian et al (2017) showed significant reduction in MAS of wrist in NMES group after training $(\mathrm{p}<0.05, \mathrm{EF}=0.145)$ and the effects were maintained for 3 months. The finding show medium proof of tonus reduction after NMES, emphasizing that this impact can be restricted to patients with more than $20^{\circ}$ active wrist extension prior to intervention.

Wrist Range of motion (ROM)

The range of active wrist extension was assessed in five RCT (Nakipoğlu et al., 2017 ; Al Dajah \& Salameh 2016 ; Kwakkel et al., 2016; Kim et al., 2015; Kim et al., 2014). The recent studies showed significant improvement of FES on wrist ROM outcome as compared to control group.. Thus, there is moderate evidence of NMES as an effective method to increase wrist ROM in patient suffering with stroke. 


\section{Journal of Exercise Science \& Physiotherapy Vol. 15 No. 2 (July to December) 2019 ISSN: 0973-2020 (Print) $\quad \mathrm{I}_{2}$ OR Impact Factor $=6.502 \quad$ ISSN: 2454-6089 (Online)}

\section{Effects of FES on functional characteristics \\ Hand Motor function}

Total fourteen RCTs assessed effect of NMES on motor function.In the included studies hand function was assessed with FMA, ARAT,WMFT. Elevan studies measured hand motor function with FMA scale (Carrico et al., 2018 ; Demir et al., 2018 ; Qian et al., 2018 ; Park et al., 2017 ; Marquez et al., 2017 ; Nakipoğlu et al., 2017 ; Schick et al., 2017 ; Kwakke et al., 2016; Wilson et al., 2016 ; Cui et al., 2015; Kim et al., 2015). Five studies included ARAT scale to check hand motor function (Carrico et al., 2018; Qian et al., 2018; Kwakkel et al., 2016 ; Cui et al., 2015; Nagapattinam et al., 2015) and three studies assessed motor function with WMFT (Carrico et al., 2018; Al Dajah \& Salameh 2016; Kwakkel et al., 2016). Qian etal (2017) showed significant improvement in FMA wrist and hand in NMES group $(\mathrm{p}<0.001) \mathrm{EFs}=0.435$ and ARAT $(\mathrm{P}<0.001)$, $\mathrm{EF}>0.279$ after the treatment. Carrico et al., (2018) found significant gains in the grip and grasp subscores of the Action Research Arm Test when compared to a control group. Statistically significant between group differences favoured the active condition on WMFT at post $(\mathrm{p}=0.04)$ and ARAT at post $(\mathrm{p}=0.02), 1$ month $(\mathrm{p}=0.01)$ and 4 month $(\mathrm{p}=0.01)$ There is strong evidence of improved motor function after NMES. But Guo et al., (2018) and Wilson et al., (2016) showed no significant improvement in FMA score of UE and hand as compared to control group.

Manual dexterity of hand

Six RCTs evaluated manual dexterity after application of NMES (Demir et al., 2018; Nakipoğlu et al., 2017; Schick et al., 2017; Kwakkel et al., 2016; Wilson et al., 2016; Kim et al., 2014) with the help of Block and Box test, J ebsen Taylor Hand function,UEFT (Nakipoğlu et al., 2017) AMAT (Wilson et al., 2016) NPHT (Kwakkel et al., 2016). Kim et al., (2015) and Schick (2016) evaluated this result after 3 Weeks of NMES using the Box and Block Test, achieving important gains compared to the control group $(\mathrm{P}<.05)$. Kim et al., (2015) and Demir et al., (2018) found a significant gain in the performance of subtests of the Jebsen Taylor Hand Function Test only for the NMES group. There is moderate evidence of the effects of NMES on manual dexterity depending on the quality of the results of the papers reviewed.

Use of upper limbs in daily routine

FIVE RCTs (Demir et al., 2018; Park et al., 2017; Kwakkel et al., 2016; Kim et al., 2015 ; Kim et al., 2014) found favourable results for NMES that measured this outcome. MAL (Demir et al., 2018; Park et al., 2017; Kwakkel et al., 2016; Kim et al., 2015), SSQOL (Kim et al., 2014) was used to assess ul function in daily activities. Park et al., (2017) showed significant improvement in in experimental group from $0.95+/-0.33$ to $2.43+/-0.51,0.99+/-0.38$ to $2.67+/-0.46$ for MAL (AOU and QOM) after 4 weeks of NMES. Demir et al., (2018) and Kwakkel et al., (2016) used the Reduced Upper Extremity Motor Activity Log test and found significant gains in the highfunctioning group compared to the control group. Nakipoglu et al (2017), also used the Upper Extremity Function Test and found a significant difference between subjects from the high and lowfunctioning groups that received NMES treatment and their respective control groups. There is strong evidence of functional gains in daily routine after NMES, with intervention appearing to having higher potential for patients with at least $20^{\circ}$ of active wrist extension before intervention.

Independence in self-care activities

Nine RCTs used self-care items of the Functional Independence Measure (Marquez et al., 2017 ; Kim et al., 2014 ), Barthel Index (Guo et al.,2018; Nakipoğlu et al., 2017; Schick et al., 2017) SF36 (Demir et al., 2018) Stroke impact Scale (Carrico et al., 2018; Kwakkel et al., 2016 ) MBI (Kim et al., 2015 ) to assess the outcome. Chin et al., (2017) showed FIM self care subscores increased 22.8(+6.7) points in the intervention group. Except for Guo et al.,(2018) all studies showed 


\section{Journal of Exercise Science \& Physiotherapy Vol. 15 No. 2 (July to December) 2019 ISSN: 0973-2020 (Print) I I OR Impact Factor $=6.502 \quad$ ISSN: 2454-6089 (Online)}

significant improvement in self care activities. There is therefore, sufficient evidence of the impact of NMES on independence.

\section{Discussion}

FES is an upcoming neuroprosthetic technique of 21 century. Researchers are still establishing the intervention parameters of FES to regain muscle strength after stroke. In the period 2008-2014 FES was used for gait rehabilitation and upper limb recovery especially deltoid, biceps and triceps strengthening. Jing et al., (2016) shifted the focus of stroke upper limb rehabilitation on hand. He concluded that hand is the driving force for upper limb recovery. Now the thrust of current studies are focussing on hand stimulation rather than arm stimulation in stroke rehabilitation. He also focused that hand recovery includes power grip and finger individuation. Therefore current study included latest RCT (2015-2018) which aims to analyse the effectiveness of surface FES stimulation of wrist extensors on neuromuscular and functional characteristics of hand in acute and subacute stroke. Earlier systematic review conducted by Yang et al., ( 2019 ) and Eraifej et al., ( 2017) established the effectiveness of FES on upper limb function (as a whole) in patients suffering from stroke. The type of current, electrode used (surface, robotic, insertional), application of electrode, site of application, muscle stimulated, were not taken in to consideration while selecting RCT. The outcome measures lack the assessment of the effect of FES on wrist ROM, wrist tone, hand power grip. The finding of the present study were supported by systematic review of Montesilva et al., (2019) which included 26 studies and revealed the effectiveness of EMG related NMES effect in restoring hand function in chronic stroke patients. It also concluded robust short term effect on body structure and function according to ICF framework, but no evidence favoured for activity and participation domains.

In the Present study all the trials used experimental methodology, comparing two or more treatments, with one control or reference group. Therefore it assesses the cause and effect relationship in the group of variables and thereby shows the causality of possible changes seen in the participants. There was random allocation of subjects in all the studies and they were classified as randomized controlled trials. Carrico et al., (2017) used simple randomization and Cui et al., (2017) used block randomization for distribution of subject in groups. Randomization does not allow selection bias influence the outcome that may predispose a group to be more susceptible to intervention impacts. Although blinding of assessors was found in SEVEN studies (Carrico et al., 2018 ; Qian et al., 2018 ; Marquez et al., 2017 ; Schick et al., 2017 ; Kwakkel et al., 2016; Kim et al.,2015; Kim et al.,2014 ) Blinding is a important element because the expectation of researcher about the evaluated result and the understanding of respondent about their therapy can affect the results of the measurement. Demir et al., (2018) did a prospective trial. Out of all assessed trials, one by Wilson et al., (2016) and Kwakkel et al., (2016) were experimental, randomized and doubleblinded studies, for evaluating the effectiveness and consistency of intervention. Kwakkel et al., (2018) found significant gains in motor function (Fulg-meyer and Action Research Arm Test), manual dexterity(WMFT,NHPT)and use of hand in daily function (MAL) in the following 3 week post-treatment phase. Gains in manual dexterity and functionality in daily life in the NMES group compared to the control group were reported by Kim et al (2015). According to the results of this systematic review electrical stimulation is safe and effective in improving wrist and hand function in sub acute stroke. Earlier application of currents in acute stage can result in better hand function as compared to application of NMES on hand in chronic stage (Jheng et al., 2019). Consolidation with more cognitive effort to initiate electrical stimulation and training in combination with functional tasks can further improve the efficacy of the treatment. It should be regarded in further research and with practitioners working with clientele. 


\section{Journal of Exercise Science \& Physiotherapy Vol. 15 No. 2 (July to December) 2019 \\ ISSN: 0973-2020 (Print) $\quad I_{2}$ OR Impact Factor $=6.502 \quad$ ISSN: 2454-6089 (Online)}

\section{Conclusion}

Randomized trials have shown beneficial impacts of NMES on affected wrist and hand despite methodological constraints, implying that NMES is efficient in encouraging the impacted hand in stroke. The finding of this systematic review research synthesizes evidence of the impact of NMES that can add to clinical behaviour of practitioner working with clientele and using NMES, favouring evidence-based practice.

\section{Search strategy: Pubmed}

\begin{tabular}{|l|l|}
\hline 01. & Stroke \\
\hline 02. & Cerebro vascular accidents \\
\hline 03. & Controlled trials \\
\hline 04. & Randomized controlled trials \\
\hline 05. & Hemiplegia \\
\hline 06. & Neuromuscular stimulation \\
\hline 07. & Functional electrical stimulation \\
\hline 08. & Electrical stimulation \\
\hline 09. & Hand \\
\hline 10. & Wrist and hand \\
\hline 11. & Upper limb \\
\hline 12. & Dexterity \\
\hline 13. & Hand function \\
\hline 14. & Finger individualization \\
\hline 15. & Sub acute stroke \\
\hline
\end{tabular}

Table 1. Data Items

\begin{tabular}{|c|c|c|c|c|c|c|}
\hline $\begin{array}{l}\text { Author's } \\
\text { Name }\end{array}$ & No. of Patients & $\begin{array}{l}\text { Documented } \\
\text { Outcomes }\end{array}$ & $\begin{array}{l}\text { Study } \\
\text { Design }\end{array}$ & Intervention & \begin{tabular}{|l} 
Statistical \\
Analysis \\
\end{tabular} & $\begin{array}{l}\text { Observed } \\
\text { Effect } \\
\end{array}$ \\
\hline $\begin{array}{l}\text { 1.Guo et al., } \\
2018\end{array}$ & $\begin{array}{l}\mathrm{N}=82 \text { pts } \\
\text { Mean age } 64.3+/- \\
11.8 \\
\text { Onset } \quad 8.8+/- \\
3.7 \text { (Months) }\end{array}$ & $\begin{array}{l}\text { 1.ARAT } \\
\text { PRE AND } \\
\text { POST } 4 \text { WK } \\
\text { 2.BI } \\
\text { 3.NRS }\end{array}$ & $\begin{array}{l}\text { Retrospective } \\
\text { Study }\end{array}$ & $\begin{array}{l}\mathrm{N}=41 \text { (Physical } \\
\text { Training) } \\
\text { Control Group } \\
\mathrm{N}=41 \text { (Experime } \\
\text { ntal Group)30 } \\
\mathrm{MIN \quad /DAY,3} \\
\mathrm{DAYS} / \mathrm{WK} \\
3 \quad \text { Sessions/wk } \\
\text { for 4wks }\end{array}$ & $\begin{array}{l}\text { SPSS } \\
\text { Version } \\
17.0 \\
\text { Fisher's } \\
\text { Exact Test } \\
\text { Mann } \\
\text { Whitney } \\
\text { Test }\end{array}$ & 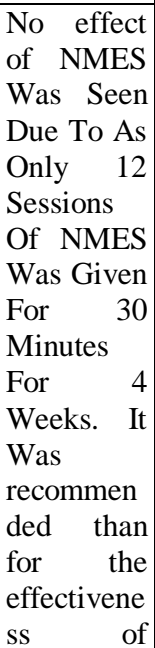 \\
\hline
\end{tabular}


Journal of Exercise Science \& Physiotherapy Vol. 15 No. 2 (July to December) 2019

ISSN: 0973-2020 (Print) $\quad \mathrm{I}_{2} \mathrm{OR}$ Impact Factor $=6.502 \quad$ ISSN: 2454-6089 (Online)

\begin{tabular}{|c|c|c|c|c|c|c|}
\hline & & & & & & $\begin{array}{l}\text { NMES } 30 \\
\text { min. } \\
\text { session for } \\
5 \text { days } \\
\text { over } 6 \text { wks } \\
\text { should be } \\
\text { given. }\end{array}$ \\
\hline $\begin{array}{l}\text { 2.Demir et } \\
\text { al., } 2018\end{array}$ & $\begin{array}{l}\text { N=17pts } \\
\text { Mean Age } \\
52.6+/-16.5, \\
\text { Onset } 306.2+/- \\
\text { 219.5 Days }\end{array}$ & $\begin{array}{l}\text { Primary } \\
\text { Outcomes } \\
\text { 1.FMA } \\
\text { 2.MAS } \\
\text { Secondary } \\
\text { Outcomes } \\
\text { 1.MAL-28 } \\
\text { 2.Jebson } \\
\text { Taylor Test } \\
\text { 3. Hand Grip } \\
\text { Strength Test } \\
\text { 4. Short } \\
\text { Form } 36\end{array}$ & $\begin{array}{l}\text { Randomized } \\
\text { Controlled } \\
\text { Prospective } \\
\text { Trial }\end{array}$ & $\begin{array}{l}\mathrm{N}=8 \text { (Standard } \\
\text { Rehabilitation) } \\
\mathrm{N}=9 \text { (FES + } \\
\text { Standard } \\
\text { Rehabilitation) } \\
\text { FES for } 45 \text { min, } \\
\text { twice a day for } \\
\text { Wrist \& Finger } \\
\text { Extensors MS } \\
5 \text { days a Week } \\
\text { over } 8 \text { Weeks }\end{array}$ & \begin{tabular}{|l|} 
SPSS \\
Version \\
15.0 \\
Chi-Square \\
Test $(\mathrm{P}<0.05$ \\
) \\
Mann \\
Whitney U \\
Test $(\mathrm{P}<0.01$ \\
$7)$
\end{tabular} & $\begin{array}{l}\text { FES + } \\
\text { Standard } \\
\text { Rehabilitat } \\
\text { ion } \\
\text { Patients } \\
\text { Showed } \\
\text { Improvem } \\
\text { ent In } \\
\text { Motor } \\
\text { Function, } \\
\text { Hand Grip } \\
\text { Strength } \\
\text { And } \\
\text { Independe } \\
\text { nce In } \\
\text { ADL'S. }\end{array}$ \\
\hline $\begin{array}{l}\text { 3. Carrico et } \\
\text { al., } 2018\end{array}$ & $\begin{array}{l}\mathrm{N}=55 \text { Acute pts } \\
\text { Mean age } 58+/- \\
12.1 \\
\text { Onset } 7.48+/-2.48 \\
\text { mths }\end{array}$ & $\begin{array}{lr}1 . & \text { W } \\
\text { MFT } & \\
2 . & \text { AR } \\
\text { AT } & \\
3 . & \text { FM } \\
\text { A } & \\
4 . & \text { SIS } \\
\text { Pre and post } \\
\text { 1 mth } \\
\text { Follow up } 4 \\
\text { mths }\end{array}$ & $\begin{array}{l}\text { Simple } \\
\text { Random } \\
\text { Allocation } \\
\text { Computer } \\
\text { Generated } \\
\text { RCT }\end{array}$ & $\begin{array}{l}18 \text { intervention } \\
\text { sessions pairing } \\
2 \quad \text { hours of } \\
\text { active }(n=33) \text { or } \\
\text { sham }(\mathrm{n}=22) \\
\text { somatosensory } \\
\text { stimulation } \\
\text { with } 4 \text { hours of } \\
\text { intensive task- } \\
\text { oriented motor } \\
\text { training. } \\
3 \text { times/wkfor } 6 \\
\text { wk }\end{array}$ & $\begin{array}{l}\text { SPSS } \\
\text { version } 9.4 \\
\text { MANOVA }\end{array}$ & $\begin{array}{l}1 . \\
\text { Statisticall } \\
y \\
\text { significant } \\
\text { between- } \\
\text { groups } \\
\text { differences } \\
\text { favoured } \\
\text { the active } \\
\text { condition } \\
\text { on Wolf } \\
\text { Motor } \\
\text { Function } \\
\text { Test at } \\
\text { post } \\
\text { (p=0.04) } \\
\text { and Action } \\
\text { Research } \\
\text { Arm Test } \\
\text { at post } \\
\text { (p=0.02), } \\
1-\text {-month } \\
\text { (p=0.01), } \\
\text { and 4- } \\
\text { month } \\
\text { (p=0.01) } \\
\text { but } \\
\text { favored } \\
\text { the sham }\end{array}$ \\
\hline
\end{tabular}


Journal of Exercise Science \& Physiotherapy Vol. 15 No. 2 (July to December) 2019

ISSN: 0973-2020 (Print) $\quad \mathrm{I}_{2} \mathrm{OR}$ Impact Factor $=6.502 \quad$ ISSN: 2454-6089 (Online)

\begin{tabular}{|c|c|c|c|c|c|c|}
\hline & & & & & & $\begin{array}{l}\text { condition } \\
\text { on Stroke } \\
\text { Impact } \\
\text { Scale at 1- } \\
\text { month } \\
\text { (p=0.03). } \\
2 \text { There } \\
\text { were no } \\
\text { significant } \\
\text { between- } \\
\text { groups } \\
\text { differences } \\
\text { on Fugl- } \\
\text { Meyer } \\
\text { Assessmen } \\
\text { t. }\end{array}$ \\
\hline $\begin{array}{l}\text { 4.Qian et al., } \\
2017\end{array}$ & $\begin{array}{l}\mathrm{N}=24 \\
\text { Mean Age } \\
54.6+/-11.3 \\
\text { Onset } 0.5-4.7 \\
\text { Mths }\end{array}$ & $\begin{array}{l}\text { 1.FMA } \\
\text { 2.MAS } \\
\text { 3.ARAT } \\
\text { 4.FIM } \\
\text { Follow Up } \\
12 \mathrm{Wk}\end{array}$ & RCT-Pilot & $\begin{array}{l}\text { N=14 } \\
\text { (Experimental } \\
\text { Group NMES } \\
\text { Robot) } \\
\text { N=10 (Control } \\
\text { Group } \\
\text { Traditional } \\
\text { Therapy) } \\
\text { FES } 20 \text { min } \\
\text { /day for } 5 \\
\text { Session/week. } \\
\text { Total 20 } \\
\text { Sessions follow } \\
\text { up } 3 \text { months }\end{array}$ & $\begin{array}{l}\text { ANOVA-2 } \\
\text { Way }\end{array}$ & $\begin{array}{l}\text { 1.Significa } \\
\text { nt } \\
\text { improvem } \\
\text { ents were } \\
\text { obtained in } \\
\text { FMA (full } \\
\text { score and } \\
\text { shoulder/ } \\
\text { elbow), } \\
\text { ARAT, } \\
\text { and FIM } \\
\text { [P<0.001, } \\
\text { effect sizes } \\
\text { (EFs) }> \\
0.279] \text { for } \\
\text { both } \\
\text { groups. } \\
\text { 2.Significa } \\
\text { nt } \\
\text { improvem } \\
\text { ent in } \\
\text { FMA } \\
\text { wrist/hand } \\
\text { was only } \\
\text { observed } \\
\text { in the } \\
\text { NMES- } \\
\text { robot } \\
\text { group (P< } \\
0.001, \text { EFs } \\
=\quad 0.435) \\
\text { after the } \\
\text { treatments. } \\
3 . \text { Significa } \\
\text { nt } \\
\text { reduction } \\
\text { in } \text { MAS }\end{array}$ \\
\hline
\end{tabular}


Journal of Exercise Science \& Physiotherapy Vol. 15 No. 2 (July to December) 2019

ISSN: 0973-2020 (Print) $\quad \mathrm{I}_{2} \mathrm{OR}$ Impact Factor $=6.502 \quad$ ISSN: 2454-6089 (Online)

\begin{tabular}{|c|c|c|c|c|c|c|}
\hline & & & & & & $\begin{array}{l}\text { wrist was } \\
\text { observed } \\
\text { in the } \\
\text { NMES- } \\
\text { robot } \\
\text { group after } \\
\text { the } \\
\text { training ( } P \\
<\quad 0.05 \text {, } \\
\text { EFs }= \\
0.145) \text { and } \\
\text { the effects } \\
\text { were } \\
\text { maintained } \\
\text { for } \\
\text { months. }\end{array}$ \\
\hline $\begin{array}{l}\text { 5. Nakipoglu } \\
, 2017\end{array}$ & $\begin{array}{l}30 \text { Stroke Pts } \\
\text { Mean Age } 60.20 \text {, } \\
\text { Range } 48-72.5, \\
\text { Onset } 4.60, \\
\text { Range } 3.3-5.9 \\
\text { months }\end{array}$ & $\begin{array}{l}\text { 1.FMA } \\
\text { 2.MAS, } \\
\text { Brunnstron } \\
\text { Hand } \\
\text { Grading } \\
\text { 3.Barthel } \\
\text { Index, UEFT }\end{array}$ & $\begin{array}{l}\text { RCT With } \\
\text { Simple } \\
\text { Randomizati } \\
\text { on }\end{array}$ & $\begin{array}{l}\text { FES GP }(15) \\
\text { CTRL GP }(15) \\
\text { FES to Wrist \& } \\
\text { Finger } \\
\text { Extensors for } \\
30 \text { min a day } \\
\text { for } 5 \text { days a } \\
\text { week } \\
\text { Total } 20 \\
\text { Sessions }\end{array}$ & \begin{tabular}{|l} 
SPSS \\
Version \\
11.0 \\
Mann \\
Whitney U \\
Test \\
$(\mathrm{P}<0.017)$ \\
Wilcoxon \\
Rank Test \\
for between \\
group
\end{tabular} & $\begin{array}{l}\text { FES group } \\
\text { shows } \\
\text { decrease in } \\
\text { spasticity } \\
\text { and } \\
\text { improved } \\
\text { ROM and } \\
\text { functional } \\
\text { measure } \\
\text { No } \\
\text { significant } \\
\text { difference } \\
\text { in ROM, } \\
\text { BI value } \\
\text { on } \\
\text { admission } \\
\text { but sig diff } \\
\text { on } \\
\text { discharge } \\
\text { No } \\
\text { significant } \\
\text { difference } \\
\text { in } \\
\text { RMA,BS, } \\
\text { UEFT in } \\
\text { ctrl group } \\
\text { Both } \\
\text { groups } \\
\text { show } \\
\text { improvem } \\
\text { ent in } \\
\text { MAS } \\
\text { Mare }\end{array}$ \\
\hline 6.Park, 2017 & $\begin{array}{l}\mathrm{N}=40 \text { Pts (Acute } \\
\text { Stroke) } \\
\text { Mean Age } \\
58.8+/-11.93 \\
\text { Onset 31.89+/- }\end{array}$ & $\begin{array}{l}\text { 1. FMA-UE } \\
\text { 2. MAL- } \\
\text { AOU - } \\
\text { QOM }\end{array}$ & $\begin{array}{l}\text { Experimental } \\
\text { Study }\end{array}$ & $\begin{array}{l}\text { EXP } \\
\mathrm{N}=20(\text { EMG } \\
\text { ES MP) }+ \text { CRT } \\
\text { CTRL } \quad \text { GP } \\
\text { N=20(Mental }\end{array}$ & $\begin{array}{l}\text { SPSS } 15.0 \\
\text { Paired t test } \\
\text { Independent }\end{array}$ & $\begin{array}{l}1 . \quad \text { The } \\
\text { experiment } \\
\text { al group } \\
\text { showed } \\
\text { significant }\end{array}$ \\
\hline
\end{tabular}


Journal of Exercise Science \& Physiotherapy Vol. 15 No. 2 (July to December) 2019

ISSN: 0973-2020 (Print) $\quad \mathrm{I}_{2} \mathrm{OR}$ Impact Factor $=6.502 \quad$ ISSN: 2454-6089 (Online)

\begin{tabular}{|c|c|c|c|c|c|c|}
\hline & 55.59 & & & $\begin{array}{l}\text { Practice) } \\
\text { +CRT } \\
\text { total treatment } \\
\text { duration } 60 \text { min } \\
\text { FES for } 30 \\
\text { minutes/day, } 5 \\
\text { days/week, for } \\
4 \text { weeks. }\end{array}$ & t test & 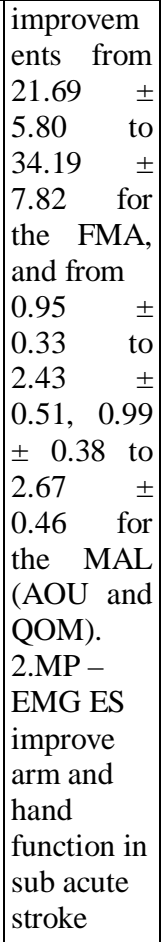 \\
\hline $\begin{array}{l}\text { 7. Salameh, } \\
2017\end{array}$ & $\begin{array}{l}\text { N=60 (Sub Acute } \\
\text { Stroke) } \\
\text { Mean Age:66.4 } \\
\text { Duration :2-6 } \\
\text { mths }\end{array}$ & $\begin{array}{l}\text { 1. WMFT } \\
\text { pre and post } \\
12 \text { week }\end{array}$ & RCT & $\begin{array}{l}\text { EXP GP N=30 } \\
\text { (NMES and } \\
\text { Functional } \\
\text { Activity) } \\
\text { CTRL GP } \\
\text { N=30 } \\
\text { (Functional } \\
\text { Activity) } \\
\text { Dorsum splint } \\
\text { was applied to } \\
\text { both gps for } \\
\text { 2x3/day hours } \\
\text { for 12 weeks. }\end{array}$ & $\begin{array}{l}\text { SPSS } \\
\text { Version } \\
20.0 \\
\text { ANCOVA } \\
\text { test } \\
\\
\end{array}$ & $\begin{array}{l}1 . \text { There } \\
\text { was } \\
\text { significant } \\
\text { difference } \\
\text { p<0.05 in t } \\
\text { test for the } \\
\text { pre and } \\
\text { posttest in } \\
\text { both } \\
\text { groups. } \\
\text { 2.Compari } \\
\text { son } \\
\text { between } \\
\text { the means } \\
\text { of the } \\
\text { posttest in } \\
\text { the } \\
\text { experiment } \\
\text { al and } \\
\text { control } \\
\text { group, } \\
\text { using } \\
\text { ANCOVA } \\
\text { test } \\
\text { showed } \\
\text { significant }\end{array}$ \\
\hline
\end{tabular}


Journal of Exercise Science \& Physiotherapy Vol. 15 No. 2 (July to December) 2019

ISSN: 0973-2020 (Print) $\quad \mathrm{I}_{2} \mathrm{OR}$ Impact Factor $=6.502 \quad$ ISSN: 2454-6089 (Online)

\begin{tabular}{|c|c|c|c|c|c|c|}
\hline & & & & & & \begin{tabular}{|l|} 
difference \\
between \\
groups \\
with \\
p<0.05 in \\
all factors \\
except for \\
index \\
finger \\
ROM and \\
reach to \\
table. \\
3. Dorsum \\
hand splint \\
and NMES \\
could be \\
helpful to \\
reduce \\
flexion \\
synergistic \\
spasticity \\
of the \\
stroke \\
hand and \\
improve \\
hand \\
functional \\
activities.
\end{tabular} \\
\hline $\begin{array}{l}\text { 8.Schick T } \\
\text { et al } 2017\end{array}$ & $\begin{array}{l}\mathrm{N}=33 \text { (Acute } \\
\text { Stroke ) } \\
\text { Mean Age 62+/- } \\
19.6 \\
\text { Onset } 51+/-32.4 \\
\text { Days }\end{array}$ & $\begin{array}{l}\text { 1.FMA } \\
\text { 2.RASP-DT } \\
\text { 3.GAS } \\
\text { 4.Barthel } \\
\text { Index } \\
\text { 5.BBT }\end{array}$ & $\begin{array}{l}\text { Randomized, } \\
\text { controlled, } \\
\text { mulicenter, } \\
\text { and single } \\
\text { (assessor) } \\
\text { blinded study }\end{array}$ & $\begin{array}{l}\text { CTRL GP- } \\
\text { EMG-ES n=16 } \\
\text { INT GP-EMG- } \\
\text { MES and MT } \\
\mathrm{n}=17 \\
5 \text { days/wk for } 30 \\
\text { min over } 3 \text { wks }\end{array}$ & $\begin{array}{l}\text { IBM SPSS- } \\
\text { Statistics } \\
\text { for } \\
\text { Windows } \\
\text { Version 22 } \\
\text { Mann- } \\
\text { Whitney } \\
\text { Test }\end{array}$ & $\begin{array}{l}\text { The } \\
\text { Interventio } \\
\mathrm{n} \quad \text { Group } \\
\text { with very } \\
\text { severe } \\
\text { paresis had } \\
\text { significantl } \\
\text { y better } \\
\text { motor } \\
\text { recovery } \\
\text { in total } \\
\text { Fugl- } \\
\text { Meyer } \\
\text { Assessmen } \\
\text { t } \\
\text { (p=0.017) } \\
\text { at } \quad \mathrm{a} \\
\text { medium } \\
\text { effect size } \\
\text { (Cohen) of } \\
\text { d = } 0.7, \\
\text { due to a } \\
\text { significant } \\
\text { recovery } \\
\text { of }\end{array}$ \\
\hline
\end{tabular}


Journal of Exercise Science \& Physiotherapy Vol. 15 No. 2 (July to December) 2019

ISSN: 0973-2020 (Print) $\quad \mathrm{I}_{2} \mathrm{OR}$ Impact Factor $=6.502 \quad$ ISSN: 2454-6089 (Online)

\begin{tabular}{|c|c|c|c|c|c|c|}
\hline & & & & & & \begin{tabular}{|l|} 
shoulder \\
and elbow \\
function \\
$(p=0.003)$ \\
in the \\
Fugl- \\
Meyer \\
Assessmen \\
t Part A \\
subtest. \\
For \\
subjects \\
with \\
severe \\
paresis, \\
additional \\
mirror \\
therapy \\
did not \\
significantl \\
y influence \\
outcome. \\
\end{tabular} \\
\hline $\begin{array}{l}\text { 9. Chin } \\
\text {,2017 }\end{array}$ & $\begin{array}{l}\mathrm{N}=21 \text { Stroke } \\
\text { Patients } \\
\text { Mean Age 58+/- } \\
18.8 \\
\text { Onset 15-57 } \\
\text { Days }\end{array}$ & $\begin{array}{l}\text { 1.FMA-UE } \\
\text { 2.FIM }\end{array}$ & \begin{tabular}{|l|} 
Assessor \\
Blind RCT
\end{tabular} & $\begin{array}{l}\mathrm{N}=10 \text { (FES } \\
\text { Group) } \\
\mathrm{N}=11 \text { (Ctrl } \\
\text { Group) } \\
45 \text { min /day } 5 \\
\text { days /wk 12-16 } \\
\text { wks }\end{array}$ & $\begin{array}{l}\text { R Version } \\
3.0 .2 \\
\text { Non } \\
\text { parameteric } \\
\text { test }\end{array}$ & \begin{tabular}{|l|} 
1.Function \\
al \\
Independe \\
nce \\
Measure \\
Self-Care \\
subscores \\
increased \\
$22.8(+6.7)$ \\
points in \\
the \\
interventio \\
n \\
group and \\
9 (+6.5) in \\
the control \\
group. \\
2 FMA- \\
UE score \\
changes \\
were 27.2 \\
$(+13.5)$ \\
and 5.3 \\
$(+11.0)$ for \\
the \\
interventio \\
n \\
control and \\
groups, \\
respectivel \\
y.
\end{tabular} \\
\hline
\end{tabular}


Journal of Exercise Science \& Physiotherapy Vol. 15 No. 2 (July to December) 2019

\begin{tabular}{|c|c|c|c|c|c|c|}
\hline & & & & & & \\
\hline $\begin{array}{l}\text { 10. Wilson et } \\
\text { al., } 2016\end{array}$ & $\begin{array}{l}\mathrm{N}=122 \text { Acute } \\
\text { Stroke PTS Mean } \\
\text { Age 55, Range } \\
\text { 47.4-65.9, Onset } \\
0.7-1.3\end{array}$ & \begin{tabular}{|l|} 
1. FMA-UE \\
pre and post \\
4 weeks \\
2.Voluntay \\
Movement of \\
Upper Limb \\
Secondary \\
Outcomes \\
1. Modified \\
AMAT \\
follow up 24 \\
wk
\end{tabular} & $\begin{array}{l}\text { Multicentred, } \\
\text { Multi Arm } \\
\text { Parallel } \\
\text { Group } \\
\text { Assessor } \\
\text { Blinded } \\
\text { RCT }\end{array}$ & $\begin{array}{l}\text { Allocation of } \\
\text { Subjects } \\
\text { N=39(Cyclic } \\
\text { NMES) } \\
\text { N=41(EMG } \\
\text { Triggered } \\
\text { NMES) } \\
\text { N=42 (Cyclic } \\
\text { Sensory } \\
\text { Stimulation) } \\
40 \text { min Session } \\
2 \text { Days in a } \\
\text { week over } 8 \\
\text { week Period } \\
\text {.Follow up } 6 \\
\text { mths }\end{array}$ & $\begin{array}{l}\text { SAS } \\
\text { Software } \\
\text { (93 } \\
\text { Version) } \\
\text { Kruskal } \\
\text { Wallis Test }\end{array}$ & 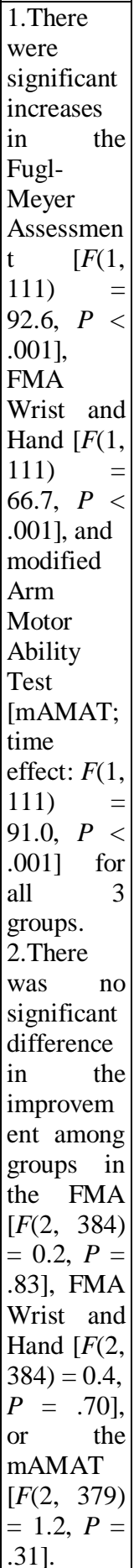 \\
\hline
\end{tabular}




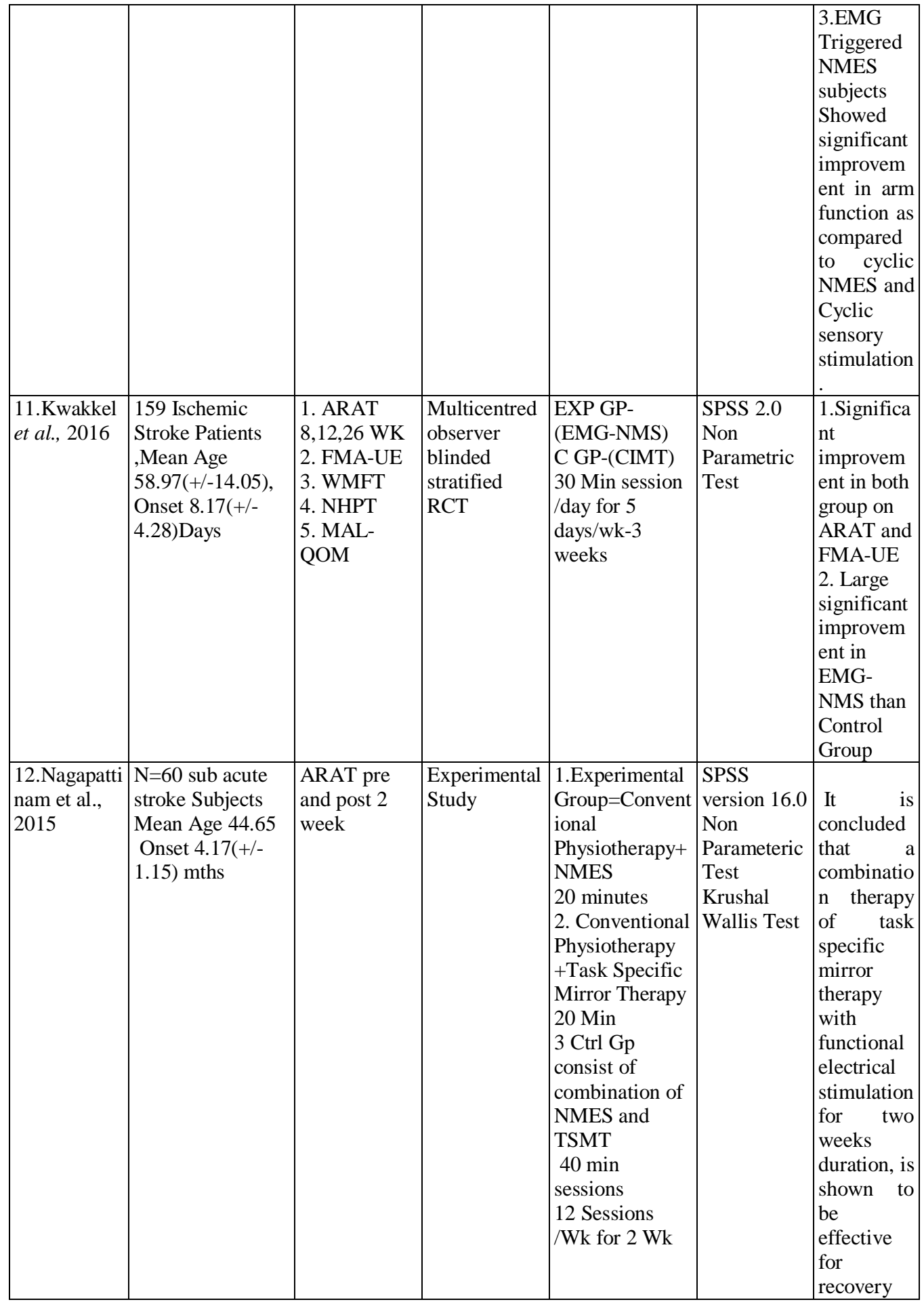




\begin{tabular}{|c|c|c|c|c|c|c|}
\hline & & & & & & $\begin{array}{l}\text { of upper } \\
\text { limb } \\
\text { function in } \\
\text { subjects } \\
\text { with sub- } \\
\text { acute } \\
\text { hemiplegia } \\
\text {. }\end{array}$ \\
\hline $\begin{array}{l}\text { 13. Kim JH, } \\
2015\end{array}$ & $\begin{array}{l}33 \\
\text { Subjects(Stroke> } \\
6 \text { Months) Age } \\
58.10+/-8.32, \\
\text { Onset 4.6-10 } \\
\text { months }\end{array}$ & $\begin{array}{l}\text { Dynameter, } \\
\text { Goniometer, } \\
\text { Box+Block } \\
\text { FIM, Jebsen } \\
\text { Taylor } \\
\text { MAS, } \\
\text { SSQOL }\end{array}$ & $\begin{array}{l}\text { RCT pre and } \\
\text { post } 4 \text { wk }\end{array}$ & $\begin{array}{l}\text { INT GP1- } \\
\text { FES+Mirror } \\
\text { Therapy+BF } \\
\text { INT GP 2- } \\
\text { FES+Mirror } \\
\text { Therapy } \\
\text { CTRL GP } \\
\text { Mirror } \\
30 \text { min session } \\
5 \text { times /wk for } \\
4 \text { wk }\end{array}$ & \begin{tabular}{|l|} 
SPSS \\
version 17.0 \\
ANOVA \\
Post hoc \\
Analysis
\end{tabular} & $\begin{array}{l}1 . \\
\text { ig UE } \\
\text { improvem } \\
\text { ent in INT } \\
\text { and CTRL } \\
\text { GP for } \\
\text { FIM, } \\
\text { BMRS, } \\
\text { BBT, MFT } \\
(\text { P<.05) } \\
2 . \\
\text { nfact FM I } \\
\text { subscore } \\
\text { for wrist } \\
\text { and hand } \\
\text { were more } \\
\text { sig than } \\
\text { INT } \\
\text { GP(p<.05) }\end{array}$ \\
\hline $\begin{array}{l}\text { 14. Tae } \\
\text { Hoon Kim } \\
\text { et al., } 2015\end{array}$ & $\begin{array}{l}\mathrm{N}=30 \\
\text { MEAN AGE } \\
59.07+/-8.07 \\
\text { ONSET } 8.27+/- \\
1.98 \text { mths }\end{array}$ & $\begin{array}{l}\text { 1.FMA-UE } \\
\text { 2.MAL } \\
\text { 3.MBI } \\
\text { 4.ROM of } \\
\text { Wrist } \\
\text { Flexion }\end{array}$ & $\begin{array}{l}\text { Blinded } \\
\text { Assessor } \\
\text {,computer } \\
\text { generated } \\
\text { RCT }\end{array}$ & $\begin{array}{l}\text { Control Group } \\
(\mathrm{N}=15) \\
\text { Conventional } \\
\text { Physiotherapy } \\
\text { Experimental } \\
\text { Group }(\mathrm{N}=15) \\
\text { BCI-FES } \\
\text { Conventional } \\
\text { Physiotherapy } \\
30 \text { min/day } 5 \\
\text { times/wk for } 4 \\
\text { weeks }\end{array}$ & $\begin{array}{l}\text { SPSS } \\
\text { Version } \\
18.0 \\
\text { Shapiro } \\
\text { Wilk Test } \\
\text { Paired T- } \\
\text { Test }\end{array}$ & $\begin{array}{l}\text { BCI-FES } \\
\text { patients } \\
\text { showed } \\
\text { significant } \\
\text { improvem } \\
\text { ent as } \\
\text { compared } \\
\text { to } \\
\text { convention } \\
\text { al } \\
\text { physiother } \\
\text { apy alone. }\end{array}$ \\
\hline $\begin{array}{l}15 . \quad \text { Cui } \\
\text { etal.,2015 }\end{array}$ & $\begin{array}{l}\mathrm{N}=45 \text { mean age } \\
61.5+/-14.8 \\
\text { onset } 12.6+/-6.1 \\
\text { weeks }\end{array}$ & $\begin{array}{l}\text { 1.FMA } \\
\text { 2. MAS } \\
\text { 3. ARAT } \\
\text { Assessment } \\
\text { before and } \\
\text { after } \\
\text { intervention, } \\
\text { and } 4 \text { weeks } \\
\text { later. }\end{array}$ & $\begin{array}{l}\text { Block } \\
\text { Randomized } \\
\text { Controlled } \\
\text { Trial }\end{array}$ & $\begin{array}{l}\text { 1. } 12 \text { H NMES } \\
\text { GP }(\mathrm{N}=15) \\
\text { 2.NMES GP } \\
(\mathrm{N}=15) \\
\text { 3. CTRL GP } \\
(\mathrm{N}=15) \\
30 \text { min session } \\
\text { /day } \\
\text { 6days/week for } \\
4 \text { weeks. }\end{array}$ & \begin{tabular}{|l|} 
SPSS \\
version 15.0 \\
ANOVA
\end{tabular} & $\begin{array}{l}\text { The 12- } \\
\text { hour } \\
\text { neuromusc } \\
\text { ular } \\
\text { electrical } \\
\text { stimulation } \\
\text { group } \\
\text { achieved } \\
\text { better } \\
\text { improvem } \\
\text { ent in } \\
\text { upper } \\
\text { extremity }\end{array}$ \\
\hline
\end{tabular}




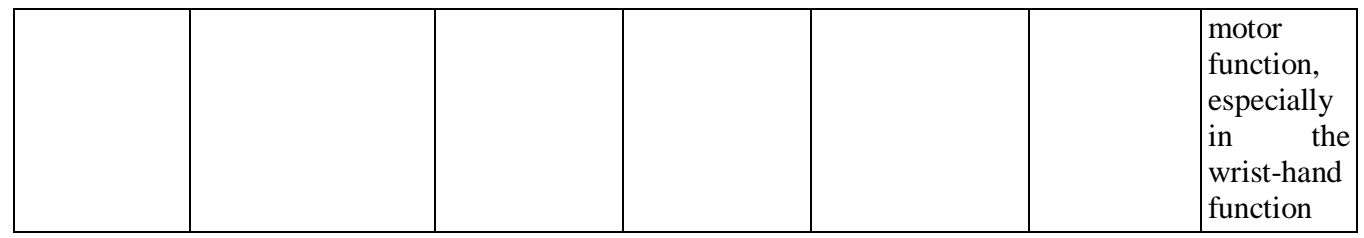

Table 2. PEDro Scale Scores

\begin{tabular}{|c|c|c|c|c|c|c|c|c|c|c|c|c|c|c|c|}
\hline & \begin{tabular}{|l|}
$\mathrm{Gu}$ \\
$\mathrm{o}$ et \\
al., \\
201 \\
8
\end{tabular} & $\begin{array}{l}\text { Dem } \\
\text { ir et } \\
\text { al., } \\
2018\end{array}$ & $\begin{array}{l}\text { Carri } \\
\text { co et } \\
\text { al } \\
.201 \\
8\end{array}$ & $\begin{array}{l}\text { Qia } \\
\text { n et } \\
\text { al., } \\
201 \\
7\end{array}$ & $\begin{array}{l}\text { Nakipog } \\
\text { lu et al., } \\
2017\end{array}$ & $\begin{array}{l}\text { Par } \\
\mathrm{k} \text { et } \\
\text { al., } \\
201 \\
7\end{array}$ & $\begin{array}{l}\text { Salam } \\
\text { eh et } \\
\text { al., } \\
2017\end{array}$ & $\begin{array}{l}\text { Schic } \\
\text { k T. } \\
\text { et al., } \\
2017\end{array}$ & $\begin{array}{l}\text { Chi } \\
\text { n et } \\
\text { al., } \\
201 \\
7\end{array}$ & $\begin{array}{l}\text { Wilso } \\
\text { n et } \\
\text { al., } \\
2016\end{array}$ & $\begin{array}{l}\text { Kwakk } \\
\text { el et } \\
\text { al., } \\
2016\end{array}$ & $\begin{array}{l}\text { Nagapatin } \\
\text { um et al., } \\
2015\end{array}$ & \begin{tabular}{|l}
$\mathrm{Ki}$ \\
$\mathrm{m}$ \\
$\mathrm{JH}$ \\
$\mathrm{et}$ \\
$\mathrm{al} .$, \\
201 \\
5
\end{tabular} & $\begin{array}{l}\text { Tae } \\
\text { hu } \\
\mathrm{Ki} \\
\mathrm{m} \\
\text { et } \\
\text { al., } \\
201 \\
5\end{array}$ & $\begin{array}{l}\text { Cui } \\
\text { et } \\
\text { al., } \\
201 \\
5\end{array}$ \\
\hline $\begin{array}{l}\text { Eligibilit } \\
\text { y criteria } \\
\text { specified }\end{array}$ & Yes & Yes & Yes & Yes & Yes & Yes & Yes & Yes & Yes & Yes & Yes & Yes & Yes & Yes & Yes \\
\hline $\begin{array}{l}\text { Random } \\
\text { allocatio } \\
n\end{array}$ & Yes & Yes & Yes & Yes & Yes & Yes & Yes & Yes & Yes & Yes & Yes & Yes & Yes & Yes & Yes \\
\hline $\begin{array}{l}\text { Conceale } \\
\text { d } \\
\text { allocatio } \\
\text { n }\end{array}$ & No & No & No & Yes & No & No & No & Yes & Yes & Yes & Yes & Yes & Yes & Yes & Yes \\
\hline $\begin{array}{l}\text { Similar } \\
\text { group at } \\
\text { baseline }\end{array}$ & Yes & Yes & Yes & Yes & Yes & Yes & Yes & Yes & Yes & Yes & Yes & Yes & Yes & Yes & Yes \\
\hline $\begin{array}{l}\text { Blinding } \\
\text { of } \\
\text { subjects }\end{array}$ & No & No & No & No & No & No & No & No & No & Yes & No & No & No & No & No \\
\hline $\begin{array}{l}\text { Blinding } \\
\text { of } \\
\text { therapies }\end{array}$ & No & No & No & No & No & No & No & No & No & Yes & No & No & No & No & No \\
\hline $\begin{array}{l}\text { Blinding } \\
\text { of } \\
\text { assessors }\end{array}$ & No & No & Yes & Yes & No & No & No & Yes & Yes & No & Yes & No & Yes & Yes & No \\
\hline $\begin{array}{l}\text { Measure } \\
\text { of one } \\
\text { key } \\
\text { outcome } \\
\text { obtained } \\
\text { for } \\
85 \% \text { of } \\
\text { subjects }\end{array}$ & Yes & Yes & Yes & Yes & Yes & Yes & Yes & Yes & Yes & Yes & Yes & Yes & Yes & Yes & Yes \\
\hline $\begin{array}{l}\text { Intention } \\
\text { to treat } \\
\text { analysis }\end{array}$ & No & No & No & No & No & No & Yes & No & No & No & Yes & Yes & No & No & No \\
\hline $\begin{array}{l}\text { Between } \\
\text { group } \\
\text { comparis } \\
\text { on of at } \\
\text { least one } \\
\text { key }\end{array}$ & Yes & Yes & Yes & Yes & Yes & Yes & Yes & Yes & Yes & Yes & Yes & Yes & Yes & Yes & Yes \\
\hline
\end{tabular}


Journal of Exercise Science \& Physiotherapy Vol. 15 No. 2 (July to December) 2019

ISSN: 0973-2020 (Print) $\mathrm{I}_{2} \mathrm{OR}$ Impact Factor $=6.502 \quad$ ISSN: 2454-6089 (Online)

\begin{tabular}{|l|l|l|l|l|l|l|l|l|l|l|l|l|l|l|}
\hline outcome & & & & & & & & & & & & \\
\hline $\begin{array}{l}\text { Point and } \\
\text { variabilit } \\
\text { y } \\
\begin{array}{l}\text { measures } \\
\text { for at } \\
\text { least one } \\
\text { key } \\
\text { outcome }\end{array}\end{array}$ & Yes & Yes & No & Yes & Yes & Yes & Yes & Yes & Yes & Yes & No & Yes & Yes & Yes \\
\hline Score & 5 & 5 & 6 & 6 & 5 & 5 & 6 & 7 & 7 & 8 & 8 & 5 & 7 & 7 \\
\hline
\end{tabular}

Table 3. Data Synthesis Criteria

\begin{tabular}{|c|c|}
\hline \multicolumn{2}{|c|}{ Level of Evidence Synthesis Criteria } \\
\hline Strong Evidence & $\begin{array}{l}\text { Provided by statistically significant finding in outcome measures in } \\
\text { - } \quad \text { Atleast } 2 \text { high quality RCT with PEDro scores of atleast } 4 \text { points* }\end{array}$ \\
\hline $\begin{array}{l}\text { Moderate } \\
\text { Evidence }\end{array}$ & $\begin{array}{l}\text { Provided by statistically significant finding in outcome measures in } \\
\text { - } \\
\text { Atleast } 1 \text { high quality RCT and } \\
\text { Atleast } 1 \text { low quality RCT( } 5 / 3 \text { points in PEDro) or } 1 \text { high quality clinical } \\
\text { controlled trial(CCT)* }\end{array}$ \\
\hline $\begin{array}{l}\text { Limited } \\
\text { Evidence }\end{array}$ & $\begin{array}{l}\text { Provided by statistically significant finding in outcome measures in } \\
\text { - Atleast } 1 \text { high quality RCT or } \\
\text { Atleast } 2 \text { high quality clinical controlled trial(CCTs)* in the absence of } \\
\text { high quality RCTs }\end{array}$ \\
\hline $\begin{array}{l}\text { Indicative } \\
\text { Findings }\end{array}$ & $\begin{array}{l}\text { Provided by statistically significant finding in outcome measures in } \\
\text { - } 1 \text { high quality CCT or low quality RCTs* (in absence of high quality } \\
\text { RCTs) } \\
\text { - Two studies of non experiment nature with sufficient quality(in absence } \\
\text { of RCTs and CCTs) }\end{array}$ \\
\hline $\begin{array}{ll}\text { Insufficient } & \text { or } \\
\text { no Evidence } & \end{array}$ & $\begin{array}{l}\text { In the event that results of eligible studies do not meet the criteria for one } \\
\text { of the above stated levels of evidence or } \\
\text { - } \quad \text { In the event of conflicting(statistically significant positive or statistically } \\
\text { significant negative)result among RCTs and CCTs or } \\
\text { - In the event of no significant studies }\end{array}$ \\
\hline \multicolumn{2}{|c|}{$\begin{array}{l}\text { *if the number of the studies that show evidence is } 50 \% \text { of the total number of the studies found within } \\
\text { same category of methodological quality and study design(RCT,CCT, non experimental studies) no } \\
\text { evidence will be classified. }\end{array}$} \\
\hline
\end{tabular}


Journal of Exercise Science \& Physiotherapy Vol. 15 No. 2 (July to December) 2019

ISSN: 0973-2020 (Print) $\quad \mathrm{I}_{2} \mathrm{OR}$ Impact Factor $=6.502 \quad$ ISSN: 2454-6089 (Online)

Table 4. Critical Appraisal Table

\begin{tabular}{|c|c|c|c|c|c|c|c|}
\hline Study & $\begin{array}{l}\text { Random } \\
\text { sequence } \\
\text { generator }\end{array}$ & $\begin{array}{l}\text { Allocation } \\
\text { concealment }\end{array}$ & $\begin{array}{l}\text { Blinding } \\
\text { of } \\
\text { participant } \\
\& \\
\text { personnel }\end{array}$ & $\begin{array}{l}\text { Blinding of } \\
\text { outcome } \\
\text { assessment }\end{array}$ & $\begin{array}{l}\text { Incomplete } \\
\text { outcome } \\
\text { data }\end{array}$ & $\begin{array}{l}\text { Selective } \\
\text { reporting }\end{array}$ & $\begin{array}{l}\text { Other } \\
\text { sourc } \\
\text { e of } \\
\text { bias }\end{array}$ \\
\hline $\begin{array}{l}\text { Guo et al } \\
(2018)\end{array}$ & Low & Low & Low & Low & Low & Low & $\begin{array}{l}\text { Uncl } \\
\text { ear }\end{array}$ \\
\hline $\begin{array}{l}\text { Demir et } \\
\text { al (2018) }\end{array}$ & Unclear & Unclear & High & High & Low & High & $\begin{array}{l}\text { Uncl } \\
\text { ear }\end{array}$ \\
\hline $\begin{array}{l}\text { Carrico et } \\
\text { al (2018) }\end{array}$ & Low & Low & High & High & Low & Low & $\begin{array}{l}\text { Uncl } \\
\text { ear }\end{array}$ \\
\hline $\begin{array}{l}\text { Qian et al } \\
(2017)\end{array}$ & Low & Unclear & High & Low & Low & High & $\begin{array}{l}\text { Uncl } \\
\text { ear }\end{array}$ \\
\hline $\begin{array}{l}\text { Nakipoglu } \\
\text { et al } \\
\text { (2017) }\end{array}$ & Low & High & High & High & Low & Low & $\begin{array}{l}\text { Uncl } \\
\text { ear }\end{array}$ \\
\hline $\begin{array}{l}\text { Park et } \\
\text { al(2017) }\end{array}$ & Low & Low & High & High & Low & High & $\begin{array}{l}\text { Uncl } \\
\text { ear }\end{array}$ \\
\hline $\begin{array}{l}\text { Salameh } \\
\text { et al } \\
(2017)\end{array}$ & Low & Low & High & High & Low & Low & $\begin{array}{l}\text { Uncl } \\
\text { ear }\end{array}$ \\
\hline $\begin{array}{l}\text { Schick T } \\
\text { et al } \\
(2017)\end{array}$ & Low & Low & High & Low & Low & Low & $\begin{array}{l}\text { Uncl } \\
\text { ear }\end{array}$ \\
\hline $\begin{array}{l}\text { Chin et al } \\
\text { (2017) }\end{array}$ & Low & Low & High & Low & Low & Low & $\begin{array}{l}\text { Uncl } \\
\text { ear }\end{array}$ \\
\hline $\begin{array}{l}\text { Wilson et } \\
\text { al (2016) }\end{array}$ & Low & Low & Low & High & Low & Low & $\begin{array}{l}\text { Uncl } \\
\text { ear }\end{array}$ \\
\hline $\begin{array}{l}\text { Kwakkel } \\
\text { et al } \\
\text { (2016) }\end{array}$ & Low & Low & Unclear & Low & Low & Low & $\begin{array}{l}\text { Uncl } \\
\text { ear }\end{array}$ \\
\hline $\begin{array}{l}\text { Nagapatti } \\
\text { num et } \\
\text { al(2015) }\end{array}$ & Unclear & Unclear & Unclear & High & Low & Unclear & $\begin{array}{l}\text { Uncl } \\
\text { ear }\end{array}$ \\
\hline $\begin{array}{l}\text { Kim JH et } \\
\text { al (2015) }\end{array}$ & Low & Low & High & Low & Low & Low & $\begin{array}{l}\text { Uncl } \\
\text { ear }\end{array}$ \\
\hline $\begin{array}{l}\text { Tae Hoon } \\
\text { Kim et al } \\
(2015)\end{array}$ & Low & Low & High & Low & Unclear & Unclear & Low \\
\hline $\begin{array}{l}\text { Cui et al } \\
(2015)\end{array}$ & Low & Low & Unclear & Unclear & Low & Unclear & $\begin{array}{l}\text { uncle } \\
\text { ar }\end{array}$ \\
\hline
\end{tabular}


Table 5. Outcome Measure Definitions with References

\begin{tabular}{|c|c|}
\hline & Description \\
\hline $\begin{array}{l}\text { Action Research } \\
\text { Arm Test (ARAT) }\end{array}$ & $\begin{array}{l}\text { ARAT qualitatively measures the ability to manipulate objects. It is split into } 4 \\
\text { subsections: grasp, grip, pinch and gross movement. }\end{array}$ \\
\hline $\begin{array}{l}\text { Fugl-Meyer } \\
\text { Assessment (FMA) }\end{array}$ & $\begin{array}{l}\text { FMA is a } 33 \text { item score that assesses movement, reflexes and coordination of the } \\
\text { upper limb on a } 3 \text { point scale }\end{array}$ \\
\hline $\begin{array}{l}\text { Modified } \\
\text { Ashworth Score } \\
\text { (MAS) }\end{array}$ & $\begin{array}{l}\text { MAS is a measure of resistance to passive movement (spasticity) of the upper } \\
\text { limb, which is rated on a } 5 \text { point scale. }\end{array}$ \\
\hline $\begin{array}{lr}\text { Motor Assessment } \\
\text { Scale: } \quad \text { Hand } \\
\text { Movement } \\
\text { (MAS HM) }\end{array}$ & $\begin{array}{l}\text { MAS examines } 9 \text { areas of motor function and scores them on a 7-point } \\
\text { qualitative scale based on participant ability to perform the relevant tasks. } \\
\text { The hand movement (HM) subscale assesses ability to perform various functional } \\
\text { movements of the hand, scoring the patient's overall performance on a scale from } \\
0-6 \text {. }\end{array}$ \\
\hline $\begin{array}{l}\text { Motor Assessment } \\
\text { Scale: Upper Arm } \\
\text { Function } \\
\text { (MAS UAF) }\end{array}$ & $\begin{array}{l}\text { MAS examines } 9 \text { areas of motor function and scores them on a 7-point } \\
\text { qualitative scale based on participant ability to perform the relevant tasks. } \\
\text { The Upper Arm Function (UAF) subscale assesses ability to perform various } \\
\text { movements of the upper arm at the shoulder joint in supine and standing } \\
\text { positions. Performance is overall scored on a scale from } 0-6 \text {. }\end{array}$ \\
\hline 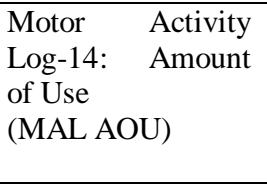 & $\begin{array}{l}\text { MAL is an interview technique that assesses subjective reporting of participants } \\
\text { on } 14 \text { common daily activities involving the upper limb. The Amount of Use } \\
\text { (AOU) subscale assigns each patient a score on an 11-point scale according to the } \\
\text { amount of use they retain of their more affected arm, as compared to their motor } \\
\text { function prior to stroke. }\end{array}$ \\
\hline $\begin{array}{l}\text { Motor Activity } \\
\text { Log-14: Quality of } \\
\text { Movement } \\
\text { (MAL QOM) }\end{array}$ & $\begin{array}{l}\text { MAL is an interview technique that assesses subjective reporting of participants } \\
\text { on } 14 \text { common daily activities involving the upper limb. The Quality of } \\
\text { Movement (QOM) subscale assigns each patient a score on an 11-point scale. } \\
\text { Their responses are scored according to how well they are now able to use their } \\
\text { more affected arm to perform specific functional activities, as compared to their } \\
\text { motor function prior to stroke. }\end{array}$ \\
\hline $\begin{array}{l}\text { Box \& Block Test } \\
\text { (BBT) }\end{array}$ & $\begin{array}{l}\text { ires participants to grasp and move a small wooden cube over a } \\
\text { in a box and drop it on the other side. The number of boxes } \\
\text { nute is then counted. }\end{array}$ \\
\hline $\begin{array}{l}\text { Barthel } \\
\text { Score } \\
\text { (BIS) }\end{array}$ & $\begin{array}{l}\text { Barthel Index is a score based on } 16 \text { items which include act ivies of daily living, } \\
\text { mobility, cognitive and social functioning. A } 4 \text { item subset of the score focuses } \\
\text { on items specifically related to activities of daily living that require the upper } \\
\text { limb. }\end{array}$ \\
\hline $\begin{array}{l}\text { Functional } \\
\text { independence } \\
\text { Measure (FIM) }\end{array}$ & $\begin{array}{l}\text { FIM is a score, originally derived from the Barthel Index, which considers } 18 \\
\text { items related to upper limb requiring activities of daily living. Participant ability } \\
\text { to perform each item independently is measured on a } 7 \text { point qualitative scale. }\end{array}$ \\
\hline $\begin{array}{l}\text { Upper Extremity } \\
\text { Function Test } \\
\text { (UEFT) }\end{array}$ & $\begin{array}{l}\text { UEFT is a measure of ability to perform common activities of daily living. } \\
\text { Participants have to complete as many repetitions of each task as they can in } 2 \\
\text { minutes. }\end{array}$ \\
\hline $\begin{array}{l}\text { Arm Mobility Arm } \\
\text { Test (AMAT) }\end{array}$ & $\begin{array}{l}\text { AMAT assess functional ability to carry out } 28 \text { upper limb specific activities } \\
\text { involving everyday objects. }\end{array}$ \\
\hline $\begin{array}{ll}\text { Chedoke } & \text { Arm \& } \\
\text { Hand } & \text { Activity } \\
\text { Inventory } & \\
\text { (CAHAI) }\end{array}$ & $\begin{array}{l}\text { CAHAI is a 7-point quantitative scale that assesses functional recovery of the } \\
\text { arm and hand post-stroke across a range of activities of daily living. Activities are } \\
\text { scored according to the patient's ability to complete them, from entirely assisted } \\
\text { to totally independent. }\end{array}$ \\
\hline
\end{tabular}


Journal of Exercise Science \& Physiotherapy Vol. 15 No. 2 (July to December) 2019

ISSN: 0973-2020 (Print) $\quad I_{2}$ OR Impact Factor $=6.502 \quad$ ISSN: 2454-6089 (Online)

Table 6. NMES Intervention characteristics

\begin{tabular}{|c|c|c|c|c|c|c|c|c|}
\hline $\begin{array}{l}\text { Author } \\
\text {,Yr }\end{array}$ & Ms Stimulated & $\begin{array}{l}\text { Session } \\
\text { Duration }\end{array}$ & $\begin{array}{l}\text { \# of } \\
\text { sessi } \\
\text { on }\end{array}$ & $\begin{array}{l}\text { Tot } \\
\text { al\# } \\
\text { hrs }\end{array}$ & $\begin{array}{l}\text { Pulse } \\
\text { width( } \\
\text { micro } \\
\text { sec) }\end{array}$ & $\begin{array}{l}\text { Frequ } \\
\text { ency } \\
(\mathbf{H z})\end{array}$ & $\begin{array}{l}\text { Du } \\
\text { ty } \\
\text { cyc } \\
\text { le }\end{array}$ & $\begin{array}{l}\text { Inten } \\
\text { sity } \\
(\mathrm{mA})\end{array}$ \\
\hline $\begin{array}{l}\text { Guo et } \\
\text { al } \\
(2018)\end{array}$ & $\begin{array}{l}\text { Wrist and finger } \\
\text { extensors(dorsum of } \\
\text { fore arm) }\end{array}$ & $\begin{array}{l}30 \min , 3 \\
\text { times /wk }\end{array}$ & $\begin{array}{l}12 \\
\text { sessi } \\
\text { ons } \\
\text { in } 4 \\
\text { wk }\end{array}$ & 6 & 300 & 40 & $\begin{array}{l}15 s \\
\text { ec } \\
\text { on/ } \\
\text { off }\end{array}$ & $\begin{array}{l}\mathrm{pt} \\
\text { tolera } \\
\text { nce }\end{array}$ \\
\hline $\begin{array}{l}\text { Demir et } \\
\text { al } \\
(2018)\end{array}$ & ED,EPL,FDS,FPL & $\begin{array}{l}45 \min , \text { twi } \\
\text { ce/day, } \\
5 \text { times/wk }\end{array}$ & $\begin{array}{l}80 \\
\text { sessi } \\
\text { ons } \\
\text { in } 8 \\
\text { wk }\end{array}$ & 60 & - & - & - & - \\
\hline $\begin{array}{l}\text { Carrico } \\
\text { et al } \\
(2018)\end{array}$ & $\begin{array}{l}\text { Opponence pollicis } \\
\text { brewis }\end{array}$ & $\begin{array}{l}120 \\
\text { min,10 wk } \\
\text { days,3 } \\
\text { times/wk }\end{array}$ & $\begin{array}{l}18 \\
\text { sessi } \\
\text { ons } \\
\text { in } 6 \\
\text { wks }\end{array}$ & 36 & 100 & 10 & - & $\begin{array}{l}50- \\
100 \\
\text { micro } \\
\text { volt }\end{array}$ \\
\hline $\begin{array}{l}\text { Qian et } \\
\text { al } \\
(2017)\end{array}$ & ECU,EDC & $\begin{array}{l}40 \mathrm{~min} \\
/ \text { day,5 } \\
\text { times /wk }\end{array}$ & $\begin{array}{l}20 \\
\text { sessi } \\
\text { ons } \\
\text { in } 4 \\
\text { wks }\end{array}$ & 13 & 100 & - & - & $80 v$ \\
\hline $\begin{array}{l}\text { Nakipog } \\
\text { lu et al } \\
(2017)\end{array}$ & $\begin{array}{l}\text { ECRL,ECRB,ECU, } \\
\text { EDC }\end{array}$ & $\begin{array}{l}30 \mathrm{~min} \\
/ \mathrm{day}, 5 \\
\text { days/wk }\end{array}$ & $\begin{array}{l}20 \\
\text { sessi } \\
\text { ons }\end{array}$ & 10 & 300 & 30 & $\begin{array}{l}10 \mathrm{~s} \\
\text { ec } \\
\text { on/ } \\
\text { off }\end{array}$ & - \\
\hline $\begin{array}{l}\text { Park et } \\
\text { al(2017) }\end{array}$ & wrist ext & $\begin{array}{l}30 \\
\text { min/day,5 } \\
\text { times/wk }\end{array}$ & $\begin{array}{l}20 \\
\text { sessi } \\
\text { ons } \\
\text { in } 4 \\
\text { wks }\end{array}$ & 10 & - & - & $\begin{array}{l}6 / 1 \\
2\end{array}$ & - \\
\hline $\begin{array}{l}\text { Salameh } \\
\text { et al } \\
(2017)\end{array}$ & ED,Supinator & $\begin{array}{l}20 \\
\text { min/day, } 6 \\
\text { times/wk }\end{array}$ & $\begin{array}{l}72 \\
\text { sessi } \\
\text { ons } \\
\text { in } 12 \\
\text { wks }\end{array}$ & 24 & - & $\begin{array}{l}150- \\
200 \mathrm{M} \\
\mathrm{H}\end{array}$ & - & $\begin{array}{l}\mathrm{pt} \\
\text { tolera } \\
\text { nce }\end{array}$ \\
\hline $\begin{array}{l}\text { Schick T } \\
\text { et al } \\
(2017)\end{array}$ & ECRL,ECRB,FDS & $\begin{array}{l}30 \mathrm{~min}, 5 \\
\text { times /wk }\end{array}$ & $\begin{array}{l}15 \\
\text { sessi } \\
\text { ons } \\
\text { in } 3 \\
\text { wks }\end{array}$ & 7.5 & 300 & $30-35$ & - & $5-60$ \\
\hline $\begin{array}{l}\text { Chin et } \\
\text { al } \\
(2017)\end{array}$ & $\begin{array}{l}\text { FCR,FCU,FDS,ED, } \\
\text { FDP,Thenar } \\
\text { Ms,Lumbricals }\end{array}$ & $\begin{array}{l}45 \\
\min / \text { day,5 } \\
\text { days /wk }\end{array}$ & $\begin{array}{l}80 \\
\text { sessi } \\
\text { ons } \\
\text { in } 16 \\
\text { wks } \\
\end{array}$ & 60 & 300 & 40 & - & 50 \\
\hline $\begin{array}{l}\text { Wilson } \\
\text { et al } \\
(2016)\end{array}$ & ECR,EDC & $\begin{array}{l}40 \mathrm{~min}, \\
\text { twice } \\
\text { /day,5 } \\
\text { times /wk }\end{array}$ & $\begin{array}{l}80 \\
\text { sessi } \\
\text { ons } \\
\text { in } 8 \\
\end{array}$ & 53 & 300 & $20-40$ & $5 / 5$ & - \\
\hline
\end{tabular}


Journal of Exercise Science \& Physiotherapy Vol. 15 No. 2 (July to December) 2019

ISSN: 0973-2020 (Print) $\quad \mathrm{I}_{2} \mathrm{OR}$ Impact Factor $=6.502 \quad$ ISSN: 2454-6089 (Online)

\begin{tabular}{|c|c|c|c|c|c|c|c|c|}
\hline & & & wks & & & & & \\
\hline $\begin{array}{l}\text { Kwakkel } \\
\text { et al } \\
\text { (2016) }\end{array}$ & Finger extensors & $\begin{array}{l}30 \mathrm{~min}, 2 \\
\text { times /day, } \\
5 \text { times } \\
\text { /wk }\end{array}$ & $\begin{array}{l}30 \\
\text { sessi } \\
\text { ons } \\
\text { in } 3 \\
\text { wks }\end{array}$ & 15 & - & - & $\begin{array}{l}5 / 2 \\
5\end{array}$ & - \\
\hline $\begin{array}{l}\text { Nagapatt } \\
\text { inum et } \\
\text { al(2015) }\end{array}$ & EDC,ECRB,ECRL & $\begin{array}{l}30 \mathrm{~min}, 6 \\
\text { times /wk }\end{array}$ & $\begin{array}{l}12 \\
\text { sessi } \\
\text { on in } \\
2 \\
\text { wee } \\
\text { ks }\end{array}$ & 6 & 250 & 35 & $\begin{array}{l}\text { 5se } \\
\text { c } \\
\text { on/ } \\
\text { off }\end{array}$ & 90 \\
\hline $\begin{array}{l}\text { Kim JH } \\
\text { et al } \\
\text { (2015) }\end{array}$ & $\begin{array}{l}\text { Wrist extensors- } \\
\text { extensor digitorum }\end{array}$ & $\begin{array}{l}30 \text { min, } 5 \\
\text { times /wk }\end{array}$ & $\begin{array}{l}20 \\
\text { sessi } \\
\text { ons } \\
\text { in } 4 \\
\text { wks }\end{array}$ & 10 & - & 256 & - & $\begin{array}{l}\mathrm{pt} \\
\text { tolera } \\
\text { nce }\end{array}$ \\
\hline $\begin{array}{l}\text { Tae } \\
\text { Hoon } \\
\text { Kim et } \\
\text { al } \\
(2015)\end{array}$ & Finger extensors & $\begin{array}{l}30 \text { min, } 5 \\
\text { times /wk }\end{array}$ & $\begin{array}{l}20 \\
\text { sessi } \\
\text { ons } \\
\text { in } 4 \\
\text { wks }\end{array}$ & 10 & 150 & 60 & $\begin{array}{l}0.5 \\
\text { sec } \\
\text { on } \\
\text { /off }\end{array}$ & $20-27$ \\
\hline $\begin{array}{l}\text { Cui et al } \\
\text { (2015) }\end{array}$ & $\begin{array}{l}\text { Wrist And Finger } \\
\text { Extensors }\end{array}$ & $\begin{array}{l}30 \mathrm{~min}, 5 \\
\text { times /wk }\end{array}$ & $\begin{array}{l}20 \\
\text { sessi } \\
\text { ons } \\
\text { in } 4 \\
\text { wks }\end{array}$ & 10 & 300 & 40 & $\begin{array}{l}1 \\
\text { sec } \\
\text { on/ } \\
\text { off }\end{array}$ & $\begin{array}{l}\mathrm{pt} \\
\text { tolera } \\
\text { nce }\end{array}$ \\
\hline
\end{tabular}

\section{References}

Al Dajah, Salameh. 2016. Effectiveness of dorsum hand splint with electrical stimulation on hand functions in stroke patients. International Journal of Health and Rehabilitation Sciences. 5. 108-117.

Carrico C. , P.M. Westgate, E. Salmon Powell, et al., 2018 .Nerve stimulation enhances task-oriented training for moderate-to-severe hemiparesis 3-12 months after stroke: a randomized trial.Am J Phys Med Rehabil. 97 pp. 808-815.

Cui BJ, Wang DQ, Qiu JQ, Huang LG, Zeng FS, Zhang Q, et al. 2015. Effects of a 12-hour neuromuscular electrical stimulation treatment program on the recovery of upper extremity function in sub-acute stroke patients: a randomized controlled pilot trial.J Phys Ther Sci. 27:23272331.10.1589/jpts.27.2327.

Demir, Y., Alacia, R., Yazicioğlu, k., Yaşar' E., Tan, and A. 2018.The effect of functional electrical stimulation on stroke recovery: A randomized control trial. JPMR Sci; 21(2): 64-70.

Eraifej, J., Clark, W.K., France, B., Desando, S., \& Moore, D.A.2017. Effectiveness of upper limb functional electrical stimulation after stroke for the improvement of activities of daily living and motor function: a systematic review and meta-analysis. Systematic Reviews. Feb 28;6(1):40

Etoh, S., Noma, T., Takiyoshi, Y., Arima, M., Ohama, R., Yokoyama, K., Kawahira, K. 2015. Effects of repetitive facilitative exercise with neuromuscular electrical stimulation, vibratory stimulation and repetitive transcranial magnetic stimulation of the hemiplegic hand in chronic stroke patients. International Journal of Neuroscience.126(11), 1007-1012

Francisco G, Chae J, Chawla H, Kirshblum S, Zorowitz R, Lewis G. 1998.Electromyogram-triggered neuromuscular stimulation for improving the arm function of acute stroke survivors: a randomized pilot study. Arch Phys Med Rehabil.; 79: 570-5. 


\section{Journal of Exercise Science \& Physiotherapy Vol. 15 No. 2 (July to December) 2019 ISSN: 0973-2020 (Print) $\quad \mathrm{I}_{2} \mathrm{OR}$ Impact Factor $=6.502 \quad$ ISSN: 2454-6089 (Online)}

Glanz, M., Klawansky, S., Stason, W., Berkey, C., \& Chalmers, T.C. 1996. Functional electrostimulation on poststroke rehabilitation: a meta-analysis of the randomized controlled trials. Archives of Physical Medicine and Rehabilitation.77, 549-553.

Gondkar, D., Khandare, S., Tai, M., Palekar, T. 2019.The effect of EMG Triggered stimulation on hand functions in patients with stroke. International Journal of basic and applied research.May;vol-9 no. 5, 1089-1099.

Gourie-Devi M. 2008. Organization of neurology services in India: unmet needs and the way forward. Neurol India. 56:4-12.

Gowland C., de Bruin H. , Basmajian JV , et al. 1992.Agonist and antagonist activity during voluntary upperlimb movement in patients with stroke. Phys Ther ; 72:624-33.

Guo, X., Fan, B., \& Mao, Y. 2018.Effectiveness of neuromuscular electrical stimulation for wrist rehabilitation after acute ischemic stroke. Medicine. 97(38).

Jheng Dao, Yang \& Liao, Chun-De \& Huang, Shihwei \& Tam, Ka-Wai \& Liou, Tsan-Hon \& Lee, Yu-Hao \& Lin, Chia-Yun \& Chen, Hung-Chou. 2019. Effectiveness of electrical stimulation therapy in improving arm function after stroke: a systematic review and a meta-analysis of randomised controlled trials. Clinical Rehabilitation. 33. 026921551983916.

Jing Xu , Adrian M. Haith , and John W. Krakauer.2016.Motor Control of the Hand Before and After Stroke. Journal of neurophysiology $\mathrm{Vol} 118$, no 2

Jonsdottir, J., Thorsen, R., Aprile, I., Galeri, S., Spannocchi, G., Beghi, E., ... Ferrarin, M. 2017. Arm rehabilitation in post stroke subjects: A randomized controlled trial on the efficacy of myoelectrically driven FES applied in a task-oriented approach. PLOS ONE.;12(12), e0188642.

Kim, J. H., \& Lee, B.-H. 2014. Mirror Therapy Combined With Biofeedback Functional Electrical Stimulation for Motor Recovery of Upper Extremities After Stroke: A Pilot Randomized Controlled Trial. Occupational Therapy International. 22(2), 51-60.

Kim, T., Kim, S., \& Lee, B. 2015.Effects of Action Observational Training Plus Brain-Computer InterfaceBased Functional Electrical Stimulation on Paretic Arm Motor Recovery in Patient with Stroke: A Randomized Controlled Trial. Occupational Therapy International. 23(1), 39-47.

Kwakkel G, Kollen BJ, van der Grond J, Prevo AJH. 2003. Probability of regaining dexterity in the flaccid upper extremity: impact of severity of paresis and time since onset in acute stroke. Stroke.,34:21812186.

Kwakkel, G, Winters, C, Van Wegen, E; EXPLICIT-Stroke Consortium. Effects of unilateral upper limb training in two distinct prognostic groups early after stroke. The EXPLICIT-stroke randomized clinical trial [published online January 7, 2016]. Neurorehabil Neural Repair

Lai S, Studenski S, Duncan PW, Perera S. 2002.Persisting consequences of stroke measured by the Stroke Impact Scale. Stroke. 33: 1840-1844.

Lee MM, Cho H-y, Song CH. 2012.The mirror therapy program enhances upper-limb motor recovery and motor function in acute stroke patients. American Journal of Physical Medicine \& Rehabilitation. 91(8):689- 700.

Marquez-Chin, C., Bagher, S., Zivanovic, V., Popovic M.R. 2017.Functional electrical stimulation therapy for severe hemiplegia: randomized control trial revisited. Can J Occup Ther. 84:87-97

Mishra NK, Khadilkar SV. 2010.Stroke program for India. Ann Indian Acad Neurol, 13: 28-32.

Monte-Silva K, Piscitelli D, Norouzi-Gheidari N, Batalla MAP, Archambault P, Levin MF.2019.Electromyogram-related neuromuscular electrical stimulation for restoring wrist and hand movement in poststroke hemiplegia: a systematic review and meta-analysis. Neurorehabil Neural Repair 33(2):96-111.

Nagapattinam, s., k, v. b., n, s. k., \& r, a. v. 2015. Effect of task specific mirror therapy with functional electrical stimulation on upper limb function for sub acute hemiplegia. International journal of physiotherapy, 2(5), 840-849.

Nakayama H, Jorgensen H, Raaschou H, Olsen T. 1994. Compensation in recovery of upper extremity function after stroke: the Copenhagen Stroke Study. Arch Phys Med Rehabil. 75:852-7.

Nakipoğlu Yuzer, G. F., Köse Dönmez, B., \& Özgirgin, N.2017. A Randomized Controlled Study: Effectiveness of Functional Electrical Stimulation on Wrist and Finger Flexor Spasticity in Hemiplegia. Journal of Stroke and Cerebrovascular Diseases, 26(7), 1467-1471. 


\section{Journal of Exercise Science \& Physiotherapy Vol. 15 No. 2 (July to December) 2019 ISSN: 0973-2020 (Print) $\quad \mathrm{I}_{2} \mathrm{OR}$ Impact Factor $=6.502 \quad$ ISSN: 2454-6089 (Online)}

Park, J. S., Choi, J. B., An, D. H., \& Chang, M. Y. 2017. Effects of mental practice combined with electromyogram-triggered electrical stimulation for upper extremity function in stroke patients. Journal of physical therapy science, 29(10), 1819-1820.

PEDro. The Physiotherapy Evidence Database Sydney: School of Physiotherapy, University of Sydney. www.pedro.org.au

Qian, Q., Hu, X., Lai, Q., Ng, S. C., Zheng, Y., \& Poon, W. 2018.Early Stroke Rehabilitation of the Upper Limb Assisted with an Electromyography-Driven Neuromuscular Electrical Stimulation-Robotic Arm. Frontier in Neurology.8.

Schick, T., Schlake, H.-P., Kallusky, J., Hohlfeld, G., Steinmetz, M., Tripp, F., Dohle, C. 2017. Synergy effects of combined multichannel EMG-triggered electrical stimulation and mirror therapy in subacute stroke patients with severe or very severe arm/hand paresis. Restorative Neurology and Neuroscience. 35(3), 319-332.

Van Peppen RP, Kwakkel G, Wood-Dauphinee S, Hendriks HJ, Van der Wees PJ, Dekker J. 2004. The impact of physical therapy on functional outcomes after stroke: what's the evidence? Clin Rehabil.;18(8):833-62.

Warlow C, van Gijn J, Dennis M.2008.Stroke:Practical Management. Blackwell Publishing Oxford, UK,.

Weingarden HP, Zeilig G, Heruti R, Shemesh Y, Ohry A, Dar 1998. A.Hybrid functional electrical stimulation orthosis system for the upper limb: effects on spasticity in chronic stable hemiplegia. Am J Phys Med Rehabil. 77(4):276-81.

Wilson, R. D., Page, S. J., Delahanty, M., Knutson, J. S., Gunzler, D. D., Sheffler, L. R., \& Chae, J. 2016. Upper-Limb Recover after Stroke. Neurorehabilitation and Neural Repair. 30(10), 978-987.

Conflict of Interest: None declared 